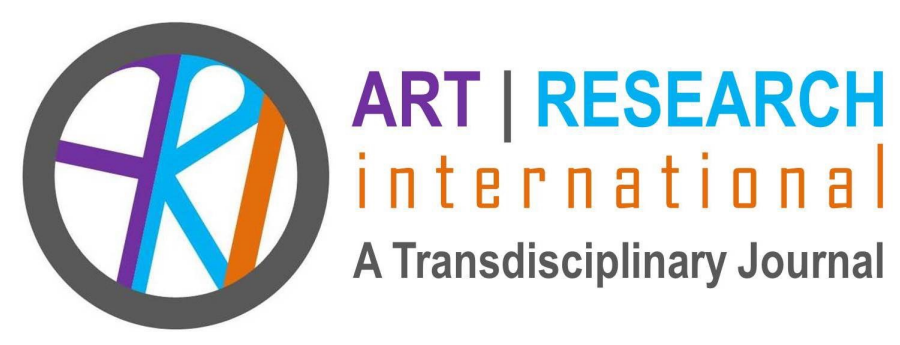

\title{
MY STAGE: PARTICIPATORY THEATRE WITH IMMIGRANT WOMEN AS A DECOLONIZING METHOD IN ART-BASED RESEARCH
}

Enni Mikkonen

University of Lapland enni.mikkonen@ulapland.fi

Mirja Hiltunen University of Lapland mirja.hiltunen@ulapland.fi

Merja Laitinen University of Lapland merja.laitinen@ulapland.fi

Enni Mikkonen is a postdoctoral researcher in Social Work and Service Design. Her research interests are art-based methods in social work, migration and social integration, decolonizing and feminist social work, critical whiteness and racialization studies, ethnography and research ethics.

Mirja Hiltunen is a professor of Art Education. Her research focuses on social engaged art and art-based action research in the North. She has published widely on community-based art education.

Merja Laitinen is a professor of Social Work. Her research interests focus on child, youth and family social work, clienthood, inter-professionality and values, sensitive research methodology and research ethics. 
Abstract: This article discusses how art-based research can function as a decolonizing research method. Its analysis is based on the collaboration of social work and art education disciplines for advancing social justice and deconstructing power dominances. Empirically, the research builds on a participatory theatre project, "My Stage," with immigrant women. The project was established as part of a larger interdisciplinary project, "Art Gear," in Northern Finland, which promoted the bidirectional integration of the local population and people with immigrant backgrounds. The research data were collected through participatory observation and reflective discussions by the social work researcher in the theatre workshops. By the analysis of an interdisciplinary team of social work and art education researchers, we develop a context-sensitive framework of art-based research to advance decolonizing research methods, which contribute to supporting the agency and inclusion of marginalized populations in research and in their integration processes at times of complex and rapid demographic and societal changes.

Keywords: art-based research; participatory theatre; social work; art education; immigration; decolonizing research method 


\section{Introduction}

Tell me and I'll forget

Show me and I may remember

Involve me and I'll understand

(Chinese proverb)

In this paper, we address an interdisciplinary research methodology that combines social work and art education disciplines and draws specific attention to ethically sound research processes that promote wellbeing and social justice of marginalized groups (Banks, 2012) through art-based research activities. While acknowledging that all research with marginalized participants is ethically fraught, including particular power imbalances and vulnerabilities of the participants, we pay specific attention to generating empathy and an inclusive sense of community with a constructive approach to research. Our particular focus is in addressing the contextual dimensions of art-based research and providing viewpoints to how it can dismantle multiple, intersecting power structures and thus function as a decolonizing research method. In doing so, we also respond to the call to increase decolonizing approaches in social work research (Deepak, 2011; Dominelli, 2010; Mikkonen, 2017; Ranta-Tyrkkö, 2010; Wehbi, Parada, George, \& Lessa, 2016).

Our interdisciplinary approach to art-based research provides a basis to address the "in-between" spaces of cultural expressions and people's agency, building on the narration and involvement of the research participants (Desyllas, 2014; Foster, 2012; Foster, Deafenbaugh, \& Miller, 2018; Määttä, 2017; Sinding, Warren, \& Paton, 2014). We approach interaction and creativity in art-based research as being products of specific cultural, social and historical contexts. We ask the following questions: 1) What are the contextual dimensions that interdisciplinary art-based research comprise regarding ethical knowledge production? 2) How can art-based methods function as bases for decolonizing, ethically sound research?

Empirically, we build the analysis on our research collaboration that addressed immigration and social integration in Northern Finland in 2016 and 2017. The research data were based on a participatory theatre project, "My Stage," with immigrant women, which was facilitated by a theatre practitioner and was established as part of a larger interdisciplinary project of art education and social work researchers, students and artists ${ }^{1}$ (Hiltunen, Mikkonen, Niskala, Douranou, \& Patrignani, 2018). The research data were collected by participatory observation and reflective research discussions of a social work researcher with the participants of the theatre workshops. The art education researcher contributed by conceiving an interdisciplinary theoretical and methodological framework and strengthening the art-based conceptualizations of the study. 
We argue that art-based methods in social work research provide specific tools and strategies to address power relations between a researcher and participants and among participants of immigrant background, that is, to seek new solutions for social problems and future visions in diverse communities and environments. As any research, art-based methods are not free from the impact of wider social hierarchies - such as colonized and racialized power structures, which are incorporated in their knowledge production and discourses (Smith, Tuck, \& Yang, 2019). While acknowledging this, we argue that art that recognizes and actively dismantles these power structures forms an ethically sensitive basis for a study with marginalized populations (Dominelli, 2010). These arguments are our foundation to address how using art-based methods can be power-sensitive and thus form a decolonizing data collection approach in social work research, which requires critical consideration on when it is and when it is not decolonizing and how to navigate power structures and tensions as they emerge.

Next, we briefly present a review of art-based research from our interdisciplinary point-of-view combining social work and art education. Then, we introduce our research data and empirical basis. Based on our analysis, we then continue to identify four contextual dimensions that comprise using art-based methods in ethically sound social work research, namely: disciplinary, social (dialogical), temporal-spatial, and societal and political. We go on to discuss the methodological contributions of developing decolonizing approaches on those contextual dimensions and how they promote ethical art-based research and the participation and agency of marginalized groups in the research processes.

\section{Interdisciplinary Art-based Methods Combining Social Work and Art Education}

In the past few decades, art-based research has become more common in social work (Foster, 2012) and more generally in the social sciences (Gergen \& Gergen, 2017; Leavy, 2017) and other disciplines such as education (Eisner, 2008). Art has the ability to be situated between fiction and fact, emotion and rationality, the concrete and the abstract, or the individual and society (Finley, 2008; Honkakoski, 2017; Leavy, 2008). This ability allows art to facilitate an understanding of the complexity around the social dynamics within immigration and social integration as well as in research relationships, perceiving them as being framed by social, political, cultural, economic, ethnic and gendered factors (Dominelli, 2010). Our approach to art-based methods resonates with activist and critical social work (Foster, 2012; Healy, 2000; Ranta-Tyrkkö, 2010) and builds on a framework of social justice (Bisman, 2004). As the nature of art is open and often unpredictable, it resonates with social work knowledge construction, which is a nuanced process that does not entail closed outcomes (Payne, 2001). Through art-based methods, social work research can develop its own professional reflexivity and self-understanding (Honkakoski, 2017). 
We focus particularly on participatory theatre as an art-based research method. Although theatre methods consist of the same elements as art-based methods generally, they are particularly embodied, illustrative and dialogical, which affects the research process and outcomes in a specific way (Kaptani \& Yuval-Davis, 2008). Participatory theatre includes bodily and interactional performativity, which expands the conventional social work research methods. We argue that theatre methods have parallels to social work research knowledge production by being culturally located and socially distributed (Dominelli, 2010; Kaptani \& Yuval-Davis, 2008). They also overlap in emphasizing the agencies of the research participants, which come into existence in social interaction.

Even though participatory theatre methods can bring new avenues to social work research to deconstruct colonial and racialized hierarchies, they are not inherently decolonial. If theatre activity is to embrace a decolonizing approach, particularly with people of immigrant backgrounds, in a context such as Northern Finland, it must dismantle the dominance of the actors of the global North over the South and the white population over people of colour, or the colonization of indigenous people (Jokela, Hiltunen, \& Härkönen, 2015b; Smith et al., 2019). This requires embracing the critical paradigm to decolonize minds and actions (Motta, 2015) and revitalize indigenous knowledge(s) (Smith et al., 2019). Decolonizing art-based research in our interdisciplinary approach means that we prioritize and visibilize immigrant women's agency and knowledge buried under colonial and Eurocentric knowledge(s) in academia (Motta, 2015; Smith et al., 2019). In doing so, we aim for understanding and bridging the diverse expectations and intentions of the participants and disciplinary knowledge bases. The research process with participatory theatre and an interdisciplinary approach includes the processes of trial and error, with the presupposition of the possibility to choose and do things differently (Hiltunen, 2010). Thus, the epistemological foundation of this article is transactional and subjectivist, based on dialogical knowledge production.

Our interdisciplinary cooperation has strengthened the notion that the social work and community-based art education fields share a common value base, and both can be used as instruments for social change (Hiltunen, 2008; Schubert \& Gray, 2015). Social work research's concern with issues of power and knowledge (Healy, 2000) aligns with community-based art education research (Hiltunen, 2008, 2009, 2010), social justice art education research (Dewenhurth, 2014; Garber, 2004) and art-based action research (Jokela, Hiltunen, \& Härkönen, 2015a; Jokela, 2017). We argue that when combined, their ability to foster sustaining, developing and regenerating communities, especially in remote northern areas, increases (Hiltunen, 2010; Jokela et al., 2015a, 2015b; Jokela, 2017). As a result, our interdisciplinary analysis is value mediated and aims at social transformation and social justice. The roles of the researchers and artists, in this regard, is advocatory and activist. We suggest that our analyses on interdisciplinarity contribute to developing artbased research methods towards a more inclusive and participatory scope. 


\section{Research Methods and Data: A Participatory Theatre Workshop with Women of Immigrant Backgrounds}

The participatory theatre project was established with women of different cultural, ethnic and national backgrounds who live in a northern town in Finland. The project included workshops with different participatory theatre modes, and it was part of a larger project, Art Gear, which aimed at developing interdisciplinary ways to respond to increased immigration (Hiltunen et al., 2018). Finland received an exceptional influx of asylum seekers in 2015 because of the so-called "refugee crisis" in Europe. This brought both challenges and possibilities to Northern Finland, where immigration in this form and to this extent was a new phenomenon (Clarke, 2009; Seppälä, Nykänen, Koikkalainen, Mikkonen, \& Rainio, 2019).

The collaboration in the project sought new ways of supporting bidirectional integration of the local populations and the newcomers. The aim of the project was to reduce the risks for harmful divisions and radicalization through art-based action. Its purpose was to promote social justice, empowerment and cohesion in the diversifying society. Integration was seen through a critical lens and as a complex process due to the overlapping power relations and hierarchies within it (Dominelli, 2010). Bidirectionality means that both newcomers and local communities engage in integrating into a changing societal and cultural environment (Clarke, 2009). By having a context-sensitive approach, we also emphasized that it is insufficient for people and communities to integrate only on a microlevel, but integration needs to be supported and promoted on contextual and structural levels, too. In this light, marginalized voices are to be recognized, and immigrants positioned as experts in their own integration process.

\section{My Stage - Participatory Theatre, Encounters and Shared Narratives}

In the "My Stage" project, a group of women met once per week in the autumn of 2016 for participatory theatre workshops. The project concluded with a performance in the spring of 2017. The workshops included art modes such as visual representations, expectation maps, storytelling, writing (Figure 1), enacting and bodystorming ${ }^{2}$, and playback theatre ${ }^{3}$. The social work researcher collected the research data in these workshops by participatory research methods, with a locally relevant and culturally sensitive approach (Mikkonen, 2017; Dominelli, 2010). The analysis was developed in a dialogical process with an art education student, who participated in the workshops and conducted a master's thesis on embracing multiculturalism through art-based workshops (Douranou, 2018).

The participants were ten women of various ages (mainly in their 20s, including one woman who was approximately 50 years old), geographical origins (South America, Middle East, Asia, and Southern and Northern Europe), cultural, ethnic and socio-economic backgrounds, language skills, current life situations and residential statuses in Finland. The theatre practitioner guided the exercises, but the participants' agency and experimental 


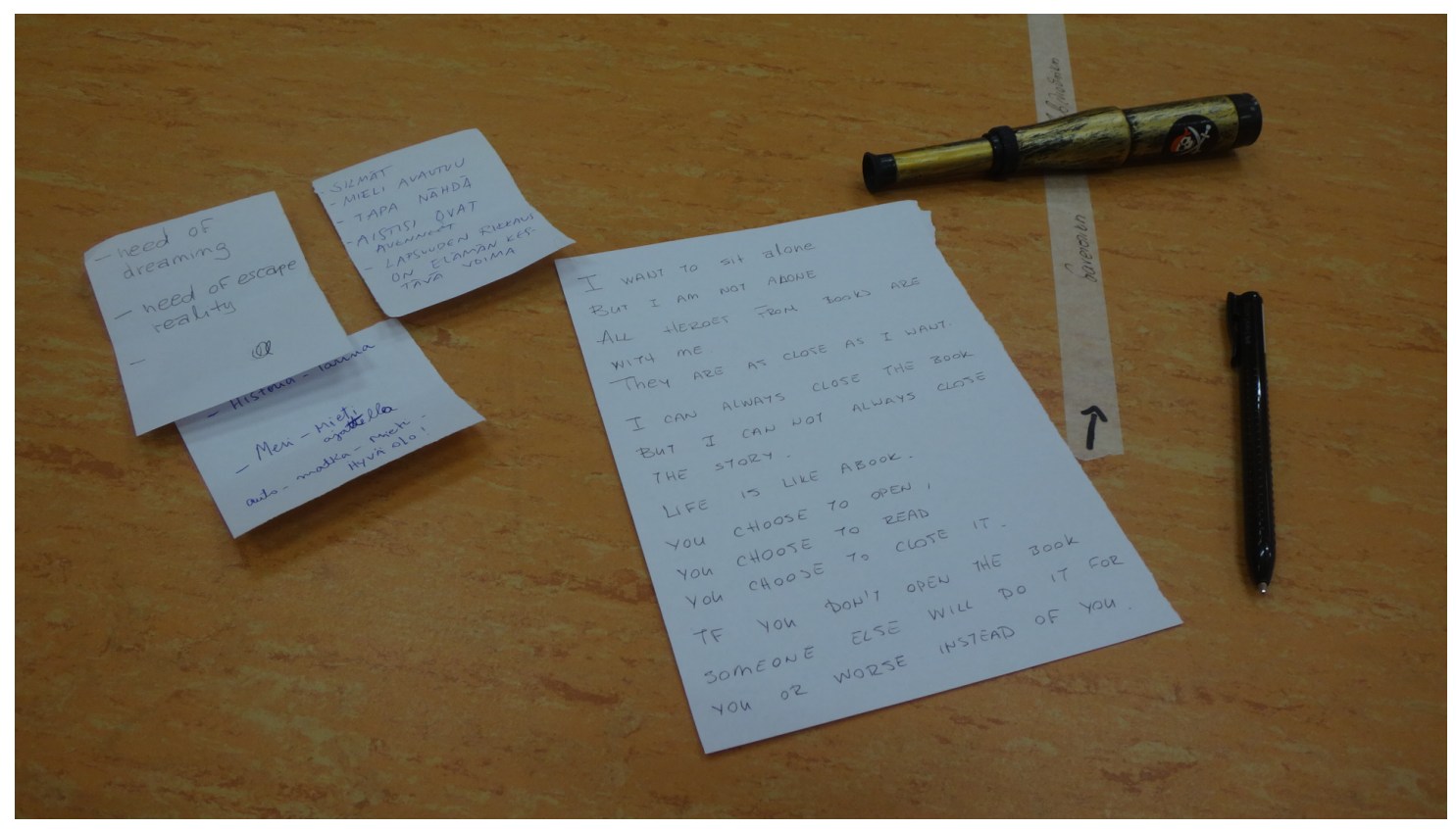

Figure 1. Participatory theatre exercises included multiple art modes, such as creative, reflective and poetic writing Photo credit: Kalomoira Douranou, 2016

action were the core of the workshops. The research data consisted of visual documentation (photographs and video clips), audio recordings of the reflective discussions at the beginning and end of the sessions, drawings and poems performed by the participants, and research notes made by the social work researcher.

The women's narratives that were co-created in the workshops were developed into a performance about "moving and staying," expressing stories of belonging and exclusion, uncertainties of journeys and the perceptions of home. The content of the performance was deepened by interviews of local people of different ages, cultural backgrounds, ethnicities and genders about their experiences of increased immigration and diversity in their social environments. The aim of the performance was to express multiple voices and stories to expand the prevalent narrative that often simplifies the experiences and representations of immigration.

Various forms of research data required multiple analysis methods (Enguix, 2014), emphasizing the contextual and situated knowledge production that is typical for ethnographic research (Behar, 1993; Coffey, 1999). The recorded discussions with the participants were analyzed through qualitative content analysis, and theoretical thematization was conducted with a decolonizing and feminist approach (Mikkonen, 2017; Morse, 1994; Motta, 2015; Spivak, 2005). The analysis process included two phases: First, we went systematically through the diverse research material, such as transcribed research 
discussions, field notes and the written texts and drawings of the participants. We divided the content of the material into different thematic categories, which led us to identify the four contextual dimensions of the art-based research. Secondly, we analyzed the content regarding the categories with specific analytical lenses determined by our theoretical framework (Motta, 2015; Spivak, 2005).

Throughout the study, the questions of ethical knowledge production and epistemological hierarchies were considered (Mikkonen, 2017; Motta, 2015). The epistemological standpoint of this study recognized that research knowledge is formed in research relationships with particular power relations. It was based on an analytical and interactional process with the research participants and was impacted by social positions and privileges, producing limits that were reflected on throughout the process. The participants' knowledge and expertise were prioritized and they were informed about their rights regarding their participation, such as the right to withdraw from the process at any point. Informed consent for using the material they produced in the workshops was gained through the signed letter of consent. The ethical sensitivity towards the participants also included protecting their anonymity and making sure that their participation did not produce any harm to them.

Creating a performance based on the participants' narratives can be seen as a form of data analysis because it involved reflective and careful consideration of which stories would be used in the performance and the best ways to represent them (Foster, 2012). This was done in collaboration with the participants, aiming at openly reflecting on the tension between the participatory data collection and the academic analysis. As the position of an academic researcher is authorized to choose, edit and organize the research knowledge (Ranta-Tyrkkö, 2010), it required reflexivity toward the epistemic power structures, creativity, and acknowledgment of the multidimensionality of knowledge and non-verbal communication of the participants.

The research encounters included reflective dialogues among the theatre practitioner, social work and art education researchers, and workshop participants throughout the process. Despite the shared aims of the project, art education and social work research are based on their own knowledge traditions; thus, continuous and critical negotiations were crucial in co-creating knowledge, formulating joint methodological commitments and stating ethical prerequisites.

\section{Results: Contextual Dimensions of the Participatory Theatre Method in Producing Ethically Sound Art-based Research}

Prior to beginning the theatre activities, there was a need for thorough consideration of ethical questions, which defined our methodological commitments. The participants' vulnerabilities, experiences of otherness and marginalization required us to commit to 
sensitivity and critical reflectivity concerning, for example, social, ethnic, class and gendered hierarchies and their intersections (Mikkonen, 2017), which emerged in the particular contexts of the art-based encounters. There is a call for developing and strengthening context-sensitive social work research (Dominelli, 2010), which functioned as our basis to consider the contextual aspects that formulated a framework for an ethically sound research process with art-based methods. Our analysis led us to identify four contextual dimensions of our art-based research: namely, disciplinary, social (dialogical), temporal-spatial, as well as societal and political aspects. Through these aspects, we discuss the co-creation of research knowledge by combining the art education and social work disciplines, and how this approach can be used as a decolonizing research method that ultimately promotes equality and social justice.

\section{Disciplinary Context}

Our interdisciplinary approach, which combined the expertise and knowledge-base of social work and art education, guided the ideological and theoretical framework of this artbased research. Prior to and during the workshops, we critically reflected on the content and aims of the project from our interdisciplinary perspective. We combined our shared disciplinary principles, namely, social justice and participation, with our methodological commitments, which aimed at creating an ethical space for meaningful encounters with the research participants. This led us to consider the participants' contextual needs, such as what they could personally gain from their participation. Our theoretical and ideological aims of promoting social justice and developing interdisciplinary working methods were negotiated and adjusted with the participants' practical needs regarding their experiences of migration and integration. We discuss this more in terms of the social context of art-based research.

The interdisciplinary theoretical basis was built on a dialogical process as an exchange of knowledge. Art education comprises the skills of art, pedagogical capabilities as art educators, and knowledge on participatory art methods (Hiltunen, 2010; Jokela, 2017). The social work approach brought a critical and social aspect to the process, namely, sensitivity to recognize the social positions, relations, marginalization and otherness that affects experiential knowledge, as well as the structural and societal impacts on the individuals' situations (Robinson, 2014). This was illustrated in an exercise where the participants visualized their lifelines by placing different provided materials into a line on the floor as symbols of their important life events. Interdisciplinary reflection during the exercise brought forth tensions around privileges and social hierarchies between the researcher and the participants. It generated discussion on the processes and social impacts of how moving to another country had been a choice for a Finnish academic woman, whereas for a Syrian woman with a refugee background, it had been a matter of survival. A combination of artbased activity and social work knowledge on otherization and marginalization deepened the understandings of social hierarchies in our interaction and personal life stories, which form a basis for dismantling unequal power hierarchies. 
As social work researchers do not necessarily engage with art and participatory theatre, cooperation with art education professionals provided advanced art methods to the research (Foster et al., 2018), which expanded the methodological scope. The interdisciplinary dialogue allowed transformation from one language into another and even more comprehensively, the transformation of one form of knowledge into another (Jokela et al., 2015a).

\section{Social (Dialogical) Context}

Participatory theatre is based on social interaction, and it occurs in a particular social context with specific social dynamics between and among the researcher, artist, participants, and audiences. The social context impacted the art-based action and the research relations, data collection methods, methodological and ethical questions, the research outcomes and the analysis process. This was concretized in the workshop exercises, such as playback theatre, in which the participants acted out the stories of other participants: some of their daily incidents expressed their difficulties to adjust to a mostly white society as a woman of colour, and social uncertainties in interacting with people of the white majority; as one of the women expressed, "I work in a shop and I don't really want to interact with people. I avoid to be in the cashier. I prefer to put the products. I am afraid that people see that I'm a foreigner and they don't like me." These exercises revealed cultural and racialized power imbalances in society and in the daily social contexts between the white academics and the artist and the research participants from ethnic and cultural minority groups.

The approach that each participant took towards the art activities was impacted by their social position, which defined their aims and needs, as well as the meaning of participation in art-based action from their perspective. Even though the workshops developed to be trustful and intimate spaces among the women, social hierarchies produced limitations for knowledge production and consequently for facilitating social change via artbased research (Mikkonen, 2017). We reflected on those limitations in our dialogues with the participants, both spontaneously and organized at the beginning and end of each session, which were supported by social work knowledge on the meaning of social context and structural inequalities in professional encounters (Dominelli, 2010).

The social context of an art-based research method impacts the processes of dialogue, which was one of the most important tools in the workshops. In addressing the experiences of immigration and integration, our dialogue was framed with multiple social borders. The question that arose related to the social and dialogical context of ethically sound art-based research was how to reach and engage with marginalized people, such as, in this case, with immigrant women, with refugee or asylum-seeker backgrounds, that set them in a particularly vulnerable position with specific needs. 
Another challenge was to find meaning to the women's involvement in the art-based action. Our research analysis emphasized that preparatory exercises and discussions prior to the participatory art-based research are crucial in building an ethical ground for the study. We viewed the process of recruiting participants to the workshops as part of the research process, which raised particular ethical questions regarding the social hierarchies and the questions of agency and subjectivity. Meeting women from a reception centre and various immigrant communities multiple times prior to the workshops formed the basis for building trust and a sense of agency in the process. The process was analyzed through interdisciplinary discussions and discussions with the women, which formed part of the research data. In addition to revealing the power hierarchies between the researchers and the participants, the process also developed ways to co-create knowledge with marginalized groups with ethical sensitivity.

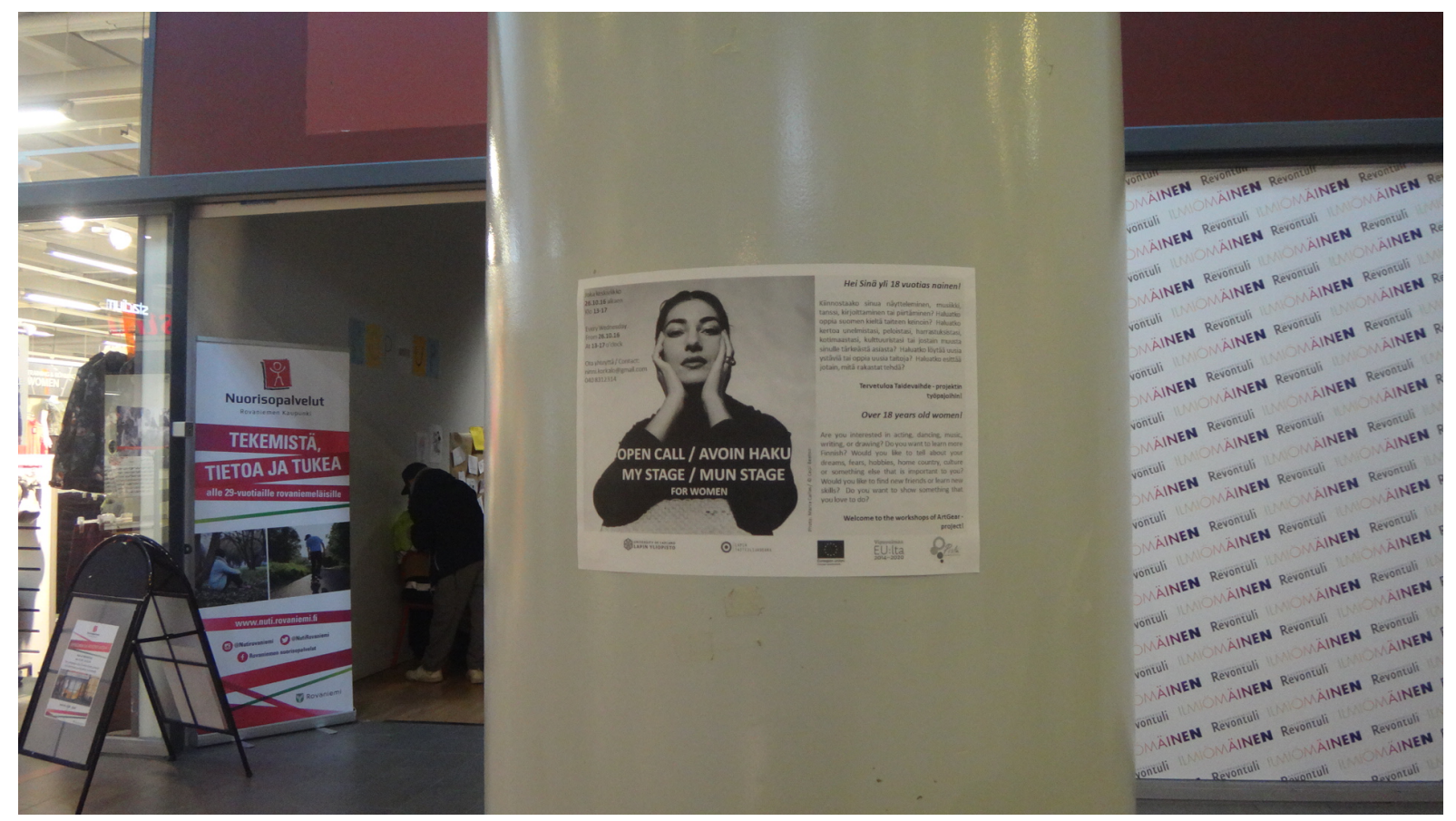

Figure 2. Poster for the workshop was pasted in different public places Photo credit: Kalomoira Douranou, 2016

To encourage women from the most marginalized positions to participate in art-based action, we designed a poster (Figure 2), developing it through a dialogical process with recognition of the women's needs and the social context. In doing so, we visited different venues where the women of immigrant backgrounds gathered together: the women's club in a local reception centre, at multicultural dance lessons and an adult education centre. The discussions with the women indicated that participating in art-based action was framed by their practical and social realities: their family responsibilities kept them busy, and some of them were waiting for their asylum decisions or information from their families in their 
countries of origin. In that respect, they did not prioritize participating in art-based action in their current life situations as such; they noted that their practical needs in terms of integration were to learn the Finnish language, get a job, or find daily stability. Participating in art-based action seemed interesting, yet not always practical, regarding their everyday lives.

The recruitment process of the participants was framed by social structures penetrated, for instance, by ethnic, socio-economic and language barriers. Our first insight in the process of getting women involved and committed to the art-based action was the importance to engage with their communities and everyday-life contexts directly, besides pasting posters about the workshop in public spaces. The process also revealed the need for investing time and effort, and required sensitive communication skills on the researcher's and artist's parts, to cross social barriers prior to the actual art-based activities, for enhancing true participation.

The recruitment process also implied that the researcher needed to step beyond the academic sphere to the participants' social contexts in terms of making art-based action meaningful for them. Cooperation with these contexts strengthens the possibilities for ethical encounters and participation that is based on the participants' agency and needs. Thus, the social context of art-based research is formed by intersections - a combination of the participants' daily contexts and academics' and artists' professional contexts, which includes epistemological power relations that need to be recognized and negotiated regarding ethical knowledge production.

Reflection on the epistemological power relations within the research process led us to conclude that building ethically sound art-based research needs to prioritize the process and not the artistic outcome, as such. Ethically sound art-based research builds trust and creates a platform for respectful research encounters, which can strengthen the emotional bonds among the participants and their commitments to the process. Our analysis indicated that when the exercises were based on experiential sharing, they revealed common social features among the participants, the artist and the researcher, in addition to the social borders and differences. These common features were, for example, some shared interests, and a feminized social position, our family position or motherhood; recognizing them strengthened trust, mutual understanding and reciprocity. For example, a woman who wore a hijab removed it during one of the workshops, which she expressed as an action of trust towards the other women. Building trustworthy relationships within the process created the ethically sound social context of the research.

\section{Temporal-Spatial Context}

Our analysis showed the importance of considering the temporal-spatial context in the encounters with the theatre workshop participants. The temporal context included questions 
about the participants' pasts in terms of the present, such as for how long each woman had been living in the particular context, and what their visions were for the future. One of the core questions in the recruitment process involved available time in the participants' everyday lives: why would they leave their other duties for the workshop? Finding an answer to this question led us to cooperate with a local adult education centre, where the women had their Finnish language lessons. We offered a chance for women to choose if they wanted to integrate the theatre workshops into their studies and thus provided an optional and interactional way to learn the language and to give practical meaning to participating in art-based action. With this combination, the temporal context was considered through the

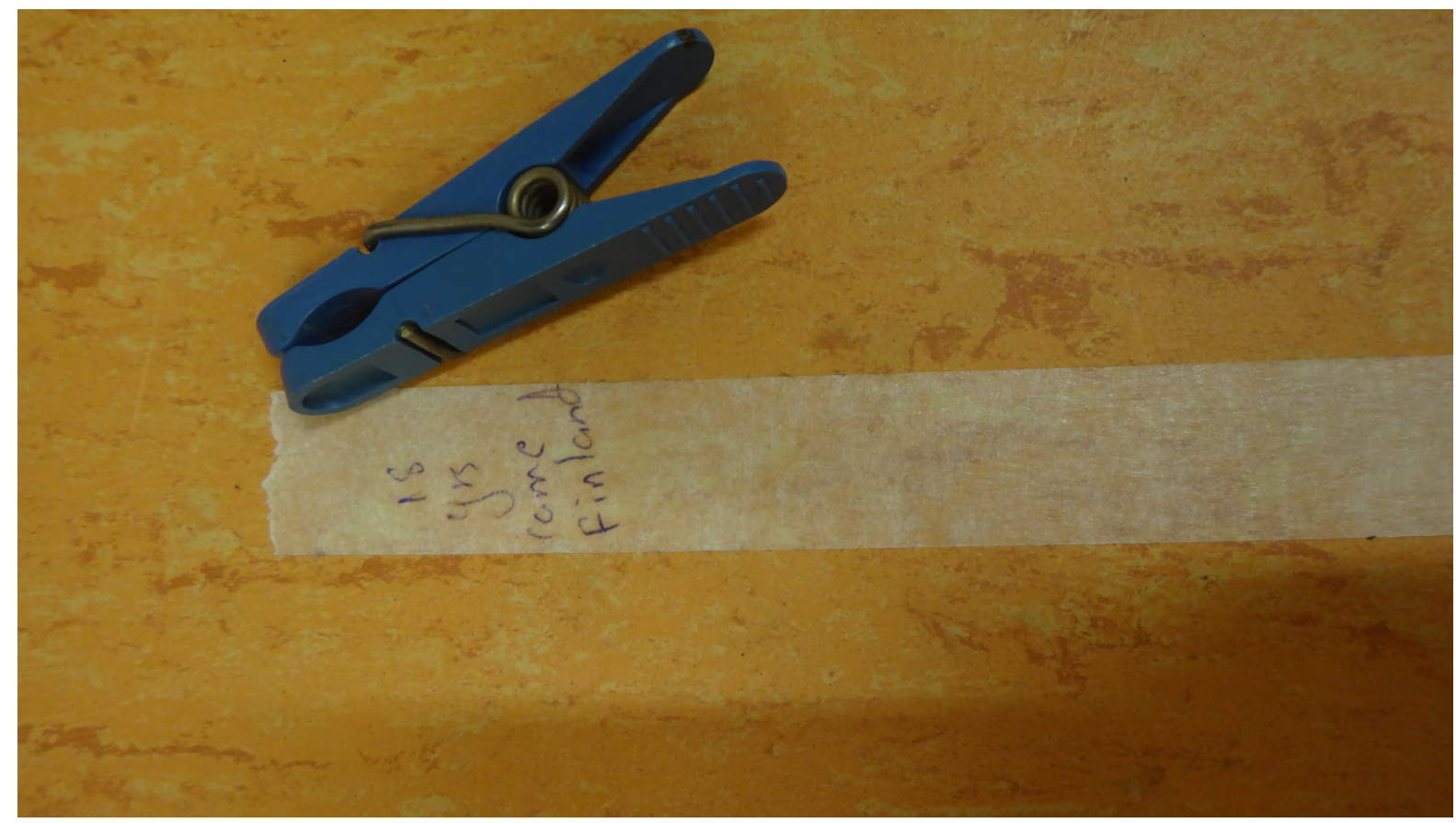

Figure 3. The past and present overlapped in different exercises, for example, in visualizing and reflecting on a timeline of the participants' important life events Photo credit: Kalomoira Douranou, 2016

participants' needs and interests, which created a platform for participatory learning in a temporally sensitive way.

The temporal context of this art-based research with immigrant women related strongly to their pasts - their time before moving to a new country. Their pasts impacted their present, for example, in how they experienced the theatre exercises and how their pasts were visualized in those exercises (Figure 3). The meaning of the temporal context was illustrated, for example, in a theatre preparatory exercise on trust, where one participant was leading another participant with closed eyes. One of the women stated that, "This was very difficult for me to do. I usually do not trust other people easily, and I get afraid." She said that 
it awakened her fear of being in the dark and brought up memories of bomb shelters in her past. This example illustrates how a theatre exercise can unexpectedly bring traumatic memories into social interaction. The participant stopped the exercise and discussed her emotions with the theatre instructor and the researcher. In listening and interpreting another person's story, there was a risk of being biased through one's own positional understanding of the world. This emphasized the importance of the ethical responsibility of the researcher to be sensitive to the different, and difficult, emotions and reactions that the exercises awakened.

In addition to the temporal context, the spatial choices of the workshops were meaningful in determining the aims and contents of the art-based action. The physical space was chosen after careful reflection on the aims of the project. The theatre workshops were organized in a closed room in the adult education centre. Our meetings created an intimate space, while simultaneously functioning as a public space, where, for example, individual emotions were revealed to the others. This duality contributed to offering a secure space that could foster intimacy, closeness and mutual sharing among the participants, as well as safety, which enabled internal learning and empowerment, thus contributing to the social value of the work. Creating safe spaces is also considered a practical response to marginalization and otherization (Smith et al., 2019).

"Safe" physical space, as such, does not guarantee a decolonizing space without critical reflection on its power structures and other spatial dimensions (Smith et al., 2019). As part of this reflective process, we acknowledged how art-based methods created entrances to emotional, spiritual and ephemeral spaces (Finley, 2008). For example, by becoming an imaginary character and exceeding one's personal limits through a theatrical exercise, the women were able to reach new emotional levels in their experiences. To build a safe psycho-emotional space, we utilized social work professional knowledge on how to deal with traumatic experiences with marginalized communities (Dominelli, 2010), which strengthened the ethical ground of the research encounters.

As the process concluded with a performance, it stepped into a public space and brought the women's stories into the public gaze. Making the private stories within a participatory process public had a different meaning for each participant. The public space revealed women's vulnerability in a different way than the closed room with trustworthy relationships. Not all participants joined the performance for various reasons, such as not being comfortable with performing in public. For those performing, it was a matter of selfexpression and being creative, and as they stated, bringing forth their stories in an alternative way. For the audience, it created the possibility to expand their knowledge on experiences of immigration from diverse perspectives. Personal hidden stories were circulated through a collective process to produce new public and shared knowledge, which was important in analyzing the intersecting power structures within the research. The 
process of making private stories public required ethical sensitivity to ensure anonymity and safety of the participants, and the process was built primarily on their agency and wishes.

The meaning of a spatial context was important not only for the participants but also regarding the dissemination of the research knowledge. As the research activities stepped out of academic spheres to diverse communities and the public (Finley, 2008), it expanded the ways of presenting the research knowledge to the audience of professionals, stakeholders, and the general public. Considering the spatial meanings produced knowledge on, for example, vulnerabilities, otherness, closeness, commonalities among different people and groups and the participatory aspect of art-based action.

Spatial and temporal contexts were intertwined in the research process. The research encounters were linked to a specific time and space. This created research relationships and knowledge that were bound spatially and temporarily to Northern Finland, in the time of tightened immigration policy since the 2015 "flow" of asylum seekers (Seppälä et al., 2019), while simultaneously increasing societal divisions (e.g., ethnic and cultural) and diversifying society and communities. Addressing the temporal-spatial context of the art-based research as part of the process established access to deeper knowledge and interaction than conventional research methods usually enable.

\section{Societal and Political Context}

The art-based research encounters were impacted by the surrounding societal and political contexts, for example, the societal position and status of the participants, such as the state of their residence permit or employment, and the researcher and artist's positions in that current societal setting. To actualize ethically sound research process, there was a need to discuss this context and address how the research and art-based methods could be used as tools to advocate for social justice on a socio-political level.

At the heart of art-based research, there is a politically grounded statement about social justice and people's participation (Finley, 2008). Art enables communities and audiences to participate in activities that aim at social change (Dewenhurt, 2014). Community art methods that step out of the academic sphere into people's everyday life contexts, with the aim at increasing participation across social divisions and facilitating change, as in this case of bidirectional integration, are activist, as such. It is radical and political to deconstruct the position of expert as a researcher who acts as a participant in diverse communities. In the workshops, the researcher and artist sought to create situations that allowed the participants to make themselves visible and heard in the process, which meant that the researcher and the artist stepped back from the "knowing" position, allowing space, listening and co-learning with the participants (Figure 4). This was politically oriented as it questioned homogenizing representations of immigrants and refugees and brought into light diverse individual experiences and their uniqueness. 


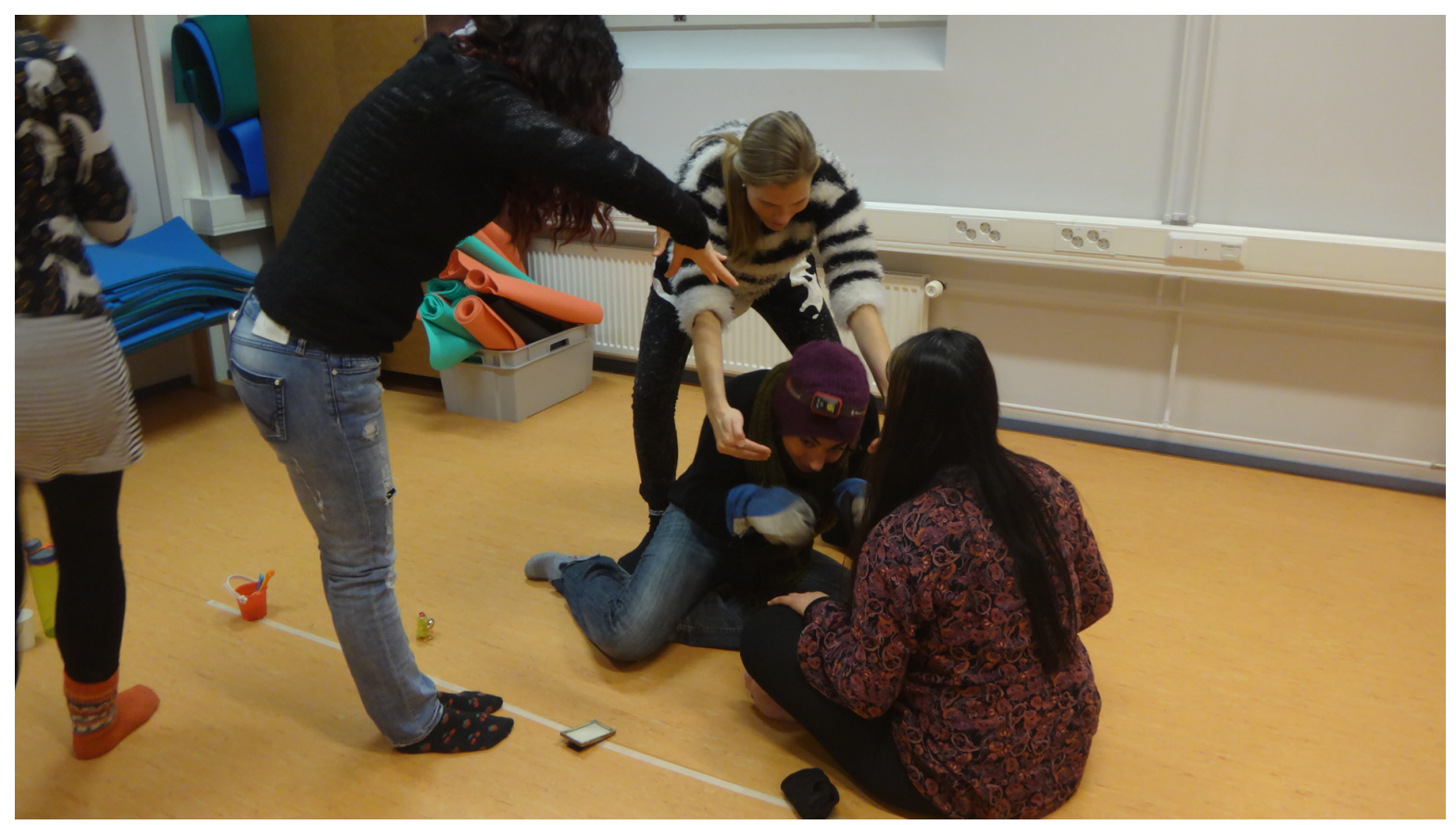

Figure 4. Co-learning with the participants included bodily and interactional exercises Photo credit: Kalomoira Douranou, 2016

In the My Stage project, the political aspect was also actualized through social advocacy and performativity. The performance presented stories about moving, staying, fear, uncertainty and change in one's personal life. It also embraced the experience of being alienated and othered. The performance was actualized in a local theatre with an open invitation. It was also presented to the local city government and social workers who were chosen to actualize political advocacy and to bring the women's experiences to political and professional levels in a creative way. When individual stories and experiences were performed, instead of presenting numbers and general knowledge about immigration, it questioned the stereotypical public image of immigration and ethnic minorities. The performance aimed at awakening the audiences to view the experiences of immigration and humanity in a new way. Performativity, as part of the research, is political and critical, and it creates new possibilities to promote social justice (Finley, 2008).

Overall, the role of art in the research can be seen as cultural activism, as alternative ways to transmit knowledge to a wider and more diverse audience beyond the academia are actualized. This needs to be done with critical reflection based on strong ethical principles, such as equal worth of people and dignity, and their links to personal and cultural values, institutions and politics (Banks, 2012; Foster, 2012). Because the performance was based on the participants' narratives through theatre, it was an important tool to raise awareness of the social dynamics and experiences concerning immigration and social integration. Our 
analysis showed that acknowledging the societal and political contexts of art-based research can promote social justice, particularly in two respects: via visibilizing the contexts' influence on the research encounters and in the participant's lives, and expanding activist research methods that target advocacy on a socio-political level.

\section{Implications for Art-based Research: Participatory Theatre as a Decolonizing Research Method}

Based on the context-sensitive analysis of the participatory theatre project, we go on to discuss how art-based methods can function as a decolonizing research method. Our analysis brought forth how the theatre workshop created space for interdisciplinary discussions and methodological development, social and dialogical processes, temporalspatial examination and societal and political advocacy. We next present the methodological outcomes of the process of decolonizing the research method on different contextual aspects (Table 1).

Analyzing the contextual aspects of the art-based action (disciplinary, social [dialogical], temporal-spatial, and societal and political) within social work research formed a basis for developing a holistic and critical approach aiming at decolonizing art-based research (Deepak, 2011; Dominelli, 2010; Motta, 2015; Spivak, 2005; Wehbi et al., 2016). Because our research combined different disciplinary knowledge bases of social work and art education, the analysis process crossed disciplinary borders in reflecting on theoretical and ideological aims and terms of social justice. Reflecting on the disciplinary context of the theatre workshop developed methodological tools and a scope for critical art-based research that promotes social justice. It created deepened understandings of marginalization and otherization, which contributes to decolonizing research (Deepak, 2011; Motta, 2015; Smith et al., 2019).

From the perspective of the social and dialogical contexts of the theatre workshops, at the core of the process of decolonizing research, there was a need to support the participants' agencies and to understand the processes and mechanisms of otherization of women who are subjected to racialization and colonization. The participants' agency was supported through mutual reflection with them on the process and methods. Agency is not an individual issue but is formed in social relations and contexts and is strengthened through a sense of community and belonging (Gangas, 2016). An important notion in terms of agency is also a refusal to act. This called for particular sensitivity on the researcher's part to view refusal or withdrawal as agency and to understand the reasons behind refusal. The study showed that the reasons could be rooted in personal experiences and emotions, but they also illustrated the restrictions in the interactions or power hierarchies within the research process. Therefore, respecting and recognizing the participants' agency - and their withdrawal and silence as a part of it, are qualities of a decolonizing research method. 


\begin{tabular}{|c|c|c|}
\hline $\begin{array}{l}\text { Contextual } \\
\text { aspects }\end{array}$ & $\begin{array}{l}\text { Processes of decolonizing the } \\
\text { research method }\end{array}$ & Methodological outcomes \\
\hline $\begin{array}{l}\text { Disciplinary } \\
\text { context }\end{array}$ & $\begin{array}{l}\text { - Interdisciplinary discussions (social } \\
\text { work and art education) - crossing } \\
\text { disciplinary borders } \\
\text { - Reflecting critically on the } \\
\text { theoretical and ideological aims and } \\
\text { terms of social justice, agencies and } \\
\text { participation of communities at the } \\
\text { margins } \\
\text { - Deepening the understanding of } \\
\text { social hierarchies, marginalization } \\
\text { and otherization in interaction and } \\
\text { personal life stories }\end{array}$ & $\begin{array}{l}\text { - Expanded methodological } \\
\text { approaches and expertise } \\
\text { - A framework for critical art- } \\
\text { based research methodology }\end{array}$ \\
\hline $\begin{array}{l}\text { Social } \\
\text { (dialogical) } \\
\text { context }\end{array}$ & $\begin{array}{l}\text { - Supporting the participants' agency } \\
\text { - Deconstructing the power structures } \\
\text { (e.g., ethnic, racialized, and colonial) } \\
\text { - Researcher's and artist's self- } \\
\text { reflection and deconstruction of } \\
\text { privileges in the interaction } \\
\text { - Renegotiating the roles of expertise; } \\
\text { prioritizing the participants' } \\
\text { knowledge } \\
\text { - Building trustworthy relationships }\end{array}$ & $\begin{array}{l}\text { - Open and creative dialogues } \\
\text { - Strengthened participation } \\
\text { and inclusion of marginalized } \\
\text { populations } \\
\text { - Deconstruction of power } \\
\text { hierarchies within the research } \\
\text { processes }\end{array}$ \\
\hline $\begin{array}{l}\text { Temporal- } \\
\text { spatial } \\
\text { context }\end{array}$ & $\begin{array}{l}\text { - Embracing the meaning } \\
\text { of participants' past, present and } \\
\text { future } \\
\text { - Reflecting on the meaning of space } \\
\text { as creating safety/connecting to a } \\
\text { local environment } \\
\text { - Recognizing participants' } \\
\text { vulnerabilities } \\
\text { - Creating emotional and spiritual } \\
\text { space for participants' self-reflection }\end{array}$ & $\begin{array}{l}\text { - Sensitive and participatory } \\
\text { methods to circulate the private } \\
\text { stories to public } \\
\text { - Increased ways of self- } \\
\text { expression of the participants } \\
\text { and knowledge production }\end{array}$ \\
\hline $\begin{array}{l}\text { Societal } \\
\text { and political } \\
\text { context }\end{array}$ & $\begin{array}{l}\text { - Recognizing and visibilizing the } \\
\text { socio-political impacts on the } \\
\text { research encounters } \\
\text { - Advocating for social justice on } \\
\text { structural and professional levels }\end{array}$ & $\begin{array}{l}\text { - Raised awareness on diverse } \\
\text { experiences of communities at } \\
\text { the margins } \\
\text { - Expanded ways of } \\
\text { disseminating the research } \\
\text { knowledge and promoting } \\
\text { public discussion on social } \\
\text { justice }\end{array}$ \\
\hline
\end{tabular}

Table 1. Contextual dimensions of a decolonizing, participatory theatre research method 
One of the main power asymmetries during the workshops was caused by Finnish language skills, which created misunderstandings among the participants and thus brought limitations to the knowledge production. However, the participatory theatre exercises functioned as a basis for non-verbal communication and increased self-confidence in the spoken language. As one participant mentioned, "Now I'm more content to handle cashier work. I talk more, and I am more confident." Particular issues - such as improving local language skills through participatory art, can increase agency in wider environments, such as one's working life. The theatre workshops facilitated the participants' possibilities to selfreflect, which supported their agency and thus functioned as a decolonizing research method.

Decolonizing research discusses the dynamics of whiteness and epistemological power, which impact the social dynamics and knowledge production of social work research (Wehbi et al., 2016). The researcher and theatre practitioner were not neutral actors, but their views were based on their social and economic positions, history, and societal and geographical contexts, as well as their personal vulnerabilities and limits (Motta, 2015). Thus, decolonizing research means that the researcher and artist, who embodied the white majority, reflected on and deconstructed their own privileges and blindness towards the otherization of the research participants. The aim is not only to declare privileges (Ahmed, 2004), but also to include a transformative goal in the process (Seppälä, 2016). This is accomplished by embracing one's own otherness, accepting discomfort as a possibility (Motta, 2015).

The process of decolonizing research required that the participants' and professionals' expertise were renegotiated and the participants' expertise was prioritized in the knowledge production. The idea of the theatre exercises was to strengthen grouping, and as the workshops progressed, the participants became familiar with each other and developed deeper interactions and trust towards one another. However, research may risk colonizing and objectifying participants if it is not brought under the control of people in their everyday lives (Finley, 2008). Participatory theatre can be based on a critical approach, as an independent grassroots social movement, or it can be a top-down process initiated by donors with specific agendas. Recognizing this tension and adding decolonizing reflection on the action strengthened the participation and inclusion of the women of immigrant backgrounds in the research.

Decolonizing research from the temporal-spatial aspect means to embrace the meaning of the participants' past, present and future in art-based research encounters. The choices of the physical space created different possibilities for decolonizing the research, such as creating a private and intimate safe space that was free from prejudices and harmful categorizations, or decolonizing the public space by connecting the participants to a local environment. Participatory theatre supported by social work professional expertise offered 
exceptional ways to create emotional and spiritual spaces for self-reflection and to expand understandings of otherization and marginalization.

The workshops showed how art-based methods are a means to say the "unsayable," in that they may bring forth issues without verbalizing them. Seeing the unsayable creates space for personal learning processes. As one of the participants stated, "I have learned a lot as a person." Dramatizing life events and playing a game or a character created emotional distance to the participants' own experiences. This helped them to access the experience of, for example, a racist assault or another painful incident (Kaptani \& YuvalDavis, 2008).

Emotional and spiritual spaces within art-based action in a social work approach functioned as a context to decolonize the research method: it included a creative means to address the participants' racialized experiences and otherization and to challenge and refine the researcher's initial understanding and knowledge in terms of the participants' experiences. Emotional and spiritual spaces present possibility for critical self-reflection for researchers and, thus, a deconstruction of the impacts of their privileges in their interactions with participants, which is a crucial part of decolonizing research.

Our analysis emphasized the importance of addressing the societal and political contexts of art-based research in developing a decolonizing research method. The political and societal contexts influenced the participants' social positions and, thus, their participation in the process; accordingly, this impacted the research knowledge. Developing a public performance with the participants raised awareness about the diverse experiences of immigration and integration from the women's perspectives and questioned the homogenization and victimization of immigrants of ethnic minorities (Robinson, 2014), which deconstructs racialized and colonized power hierarchies. On the other hand, performing in public included a risk of simplifying the women's narratives and losing the authentic voice of those who did not perform, which created a shortcoming to decolonizing research. This was mitigated by the involvement of the participants in the writing phase of the performance and with critical reflexivity in a dialogical process.

To obtain information from the margins required effort, negotiation skills, the flexibility of the researcher and the artist and their ability to recognize and question power structures. It was a complex process with a risk of epistemological blindness, especially when the actors had internalized power relations that were sometimes hidden and difficult to recognize. Yet, participatory theatre is not inherently free from unequal power structures; it can function as a way to express and understand the nuances of knowledge and marginalized and silenced voices that are sometimes more informative than the dominant voices, which can even out unbalanced power dynamics. Through such a standpoint, we argue that embracing interdisciplinary art-based research with the combination of social 
work and art education can function as a basis to develop a decolonizing research method and strengthen inclusive and socially just research and art processes.

\section{Conclusion}

In this article, we discussed how using participatory theatre, and more widely, artbased research methods in social work research, can function as decolonizing research. We discussed a context-sensitive research approach with critical scrutiny of power structures, privileges and marginalizations. We suggest that as a result of a thorough contextual analysis with a decolonizing approach, interdisciplinary art-based research can foster and strengthen the participation and agency of people subjected to marginalization and otherization, through, for example, their positions as asylum seeker or immigrant of an ethnic minority. Our conclusion is that developing context-sensitive and decolonizing art-based research is needed, particularly at the time of complex and rapid demographic changes, and due to the increasing need for producing research knowledge that promotes inclusion, coherence and social justice.

\section{Acknowledgements}

We are grateful for European Social Fund for funding our project "Art Gear: Bidirectional integration supporting young people" (S20588: 2016-2018) that this paper is based on. We would also like to thank the research participants and collaborators for making this article possible, as well as two anonymous reviewers of this article for their constructive comments. 


\section{REFERENCES}

Ahmed, S. (2004). Declarations of whiteness: The non-performativity of anti-racism.

Borderlands ejournal, 3(2). Retrieved from http://www.borderlands.net.au/vol3no2 2004/ ahmed declarations.htm

Banks, S. (2012). Ethics and values in social work (4th ed.). Basingstoke: Palgrave Macmillan.

Behar, R. (1993). Translated woman: Crossing the border with Esperanza's story. Boston, MA: Beacon Press.

Bisman, C. (2004). Social work values: The moral core of the profession. British Journal of Social Work, 34(1), 109-123.

Clarke, K. (2009). Negotiating migrant community needs through social work research: A Finnish example. Qualitative Social Work, 10(1), 8-27.

Coffey, A. (1999). The ethnographic self: Fieldwork and the representation of identity. London: SAGE.

Deepak, A. C. (2011). Globalization, power and resistance: Postcolonial and transnational feminist perspectives for social work practice. International Social Work, 55(6), 779-793.

Desyllas, M. C. (2014). Using photovoice with sex workers: The power of art, agency and resistance. Qualitative Social Work, 13(4), 477-501.

Dewenhurt, M. (2014). Social justice art. A framework for activist art pedagogy. Cambridge: Harvard Education press.

Dominelli, L. (2010). Social work in a globalizing world. Cambridge, UK: Polity Press.

Douranou, K. (2018). Embrace multiculturalism through arts-based workshops: Qualitative evaluation using visual representations (Master's thesis). Retrieved from Lauda. (http://urn.fi/URN:NBN:fi-fe2018062026224)

Eisner, E. W. (2008). Persistent tensions in arts-based research. In M. Cahnmann-Taylor \& R. Siegesmund (Eds.), Arts-based research in education: Foundations for practice (pp. 16-27). New York: Routledge.

Enguix, B. (2014). Negotiating the field: Rethinking ethnographic authority, experience and the frontiers of research. Qualitative Research, 14(1), 79-94.

Finley, S. (2008). Arts-based research. In J. G. Knowles \& A. L. Cole (Eds.), Handbook of the arts in qualitative research: Perspectives, methodologies, examples, and issues (pp. 71-82). Thousand Oaks, CA: SAGE Publications. 
Foster, V. (2012). The pleasure principle: employing arts-based methods in social work research. European Journal of Social Work, 15(4), 532-545.

Foster, L. J., Deafenbaugh, L. \& Miller, E. (2018). Group metaphor map making: Application to integrated arts-based focus groups. Qualitative Social Work, 17(2), 305-322.

Fox, H. (2007). Playback theatre: Inciting dialogue and building community through personal story. The Drama Review, 51(4), 89-10.

Gangas, S. (2016). From agency to capabilities: Sen and sociological theory. Current Sociology, 64(1), 22-40.

Garber, E. (2004). Social justice and art education. Visual Art Research, 30(2), 4-22.

Gergen, K. \& Gergen, M. (2017). The performative movement in social science. In P. Leavy (Ed.), Handbook of arts-Based research (pp. 54-67). New York: Guilford.

Healy, K. (2000). Social work practices: Contemporary perspectives on change. London: Sage.

Hiltunen, M., Mikkonen, E., Niskala, A., Douranou, M. \& Patrignani, E. (2018). My stage sharing and creating a story of our past, present, and future in Finnish Lapland. Synnyt/ Origins: Finnish Studies in Art Education, 1, 1-19.

Hiltunen, M. (2010). Slow activism: Art in progress in the north. In A. Linjakumpu \& S. Wallenius-Korkalo (Eds.), Progress or perish. Northern perspectives on social change (pp. 119-138). Farnham, UK: Ashgate.

Hiltunen, M. (2009). Yhteisöllinen taidekasvatus. Performatiivisesti pohjoisen sosiokulttuurisissa ympäristöissä/Community-based art education. Through performativity in the Northern sociocultural environments (Doctoral dissertation). Retrieved from Lauda. (http://urn.fi/URN:NBN:fi:ula-20111141039)

Hiltunen, M. (2008). Community-based art education in the north - a space for agency? In G. Coutts, \& T. Jokela (Eds.), Art community and environment. Educational perspectives (pp. 91-112), Bristol, UK: Intellect Books.

Honkakoski, A. (2017). Taiteen ja sosiaalisen työn rajalla - kohtauspaikkana draama/At the borders of art and social work - drama as a place to encounters (Doctoral dissertation). Retrieved from Lauda. (http://urn.fi/URN:ISBN:978-952-484-950-0)

Jokela, T. (2017). Art of art education through art-based action research for the north. In M. Fritzsche \& A. Schnur (Eds.), Fokussierte komplexität - Ebenen von kunst und bildung/ Focused complexity - Levels of arts and education, (pp. 55-67). Oberhausen, DE: ATHENA.

Jokela, T., Hiltunen, M., \& Härkönen, E. (2015a). Art-based action research - Participatory art for the north. International Journal for Education through Art, 11(3), 433-448. 
Jokela, T., Hiltunen, M., \& Härkönen, E. (2015b). Contemporary art education meets the international multicultural north. In M. Tavin \& J. Pullinen (Eds.), Conversations on Finnish art education (pp. 260-276). Helsinki, FI: Aalto Arts Books.

Kaptani, E. \& Yuval-Davis, N. (2008). Participatory theatre as a research methodology: Identity, performance and social action among refugees. Sociological Research Online, 13(1), 1-12.

Leavy, P. (Ed.) (2017). Handbook of arts-based research. New York: Guilford Press.

Leavy, P. (2008). Method meets art: Arts-based research practice. New York: Guilford Press.

Mikkonen, E. (2017). Bridges over the mountain ranges: Ethnography on the complexities of transition in women's social position in Nepalese rural communities (Doctoral dissertation). Retrieved from Lauda. (http://urn.fi/URN:ISBN: 978-952-337-009-8)

Morse, J. M. (1994). "Emerging from the data": The cognitive processes of analysis in qualitative inquiry. In J. M., Morse (Ed.). Critical issues in qualitative research methods (pp. 23-43). Thousand Oaks, CA: SAGE Publications.

Motta, S. (2015). Becoming woman: On exile and belonging to the borderlands. In Z. Arashiro \& M. Barahona (Eds.), Women in academia crossing north-south borders: Gender, race and displacement (pp. 89-116). London, UK: Lexington Books.

Määttä, T. (2017). Broadening social work's framework on place and belonging: An investigation into identity processes intersected by experiences of migration. British Journal of Social Work, 48(6), 1594-1610.

Payne, M. (2001). Knowledge bases and knowledge biases in social work. Journal of Social Work, 1(2), 133-146.

Ranta-Tyrkkö, S. (2010). At the intersection of theatre and social work in Orissa, India: Natya Chetana and its theatre. Tampere, FI: Tampere University Press.

Robinson, K. (2014). Voices from the Front Line: Social Work with Refugees and Asylum Seekers in Australia and the UK. British Journal of Social Work, 44, 1602-1620.

Santos, A., Garcia, A. M., Alves, M. C., \& Silveira, E. L. (2018). Bodystorming: Lessons learnt from its use on a service design undergraduate discipline. ServDes2018 - Service Design Proof of Concept. Politecnico di Milano. Retrieved from: http://www.servdes.org/ wp/wp-content/uploads/2018/07/17.pdf

Schubert, L. \& Gray, M. (2015). Critical commentary: The death of emancipatory social work as art and birth of socially engaged art practice. British Journal of Social Work, 45, 13491356. 
Seppälä, T., Nykänen, T., Koikkalainen, S., Mikkonen, E. \& Rainio, M. (2019). In-between space/time: Affective exceptionality during the "refugee crisis" in Northern Finland. Nordic Journal of Migration Research, 9(4). DOI: 10.2478/njmr-2019-0029.

Seppälä, T. (2016). Feminizing resistance, decolonizing solidarity: Contesting neoliberal development in the global south. Journal of Resistance Studies, 2(1), 12-47.

Sinding, C, Warren, R. \& Paton, C. (2014). Social work and the arts: Images at the intersection. Qualitative Social Work, 13(2), 187-202.

Smith, T. S., Tuck, E. \& Yang, K. W. (2019). Introduction. In T. S. Smith, E. Tuck, \& K. W. Yang (Eds.), Indigenous and decolonizing studies in education. Mapping the long view. New York: Routledge.

Spivak, G. (2005). The use and abuse of human rights: A revised version of an essay in South Atlantic Quarterly under the title "righting wrongs". Boundary 2, 32(1), 131-191.

Wehbi, S., Parada, H., George, P., \& Lessa, I. (2016). Going home: Social work across and about borders. International Social Work, 59(2), 284-292.

\section{ENDNOTES}

1 Art Gear - Bidirectional integration supporting young people [Taidevaihde Kaksisuuntainen kotoutuminen nuorten tukena] (S20588), European Social Fund, (1.1.2016-31.12.2018) https://www.facebook.com/pg/Taidevaihde-ArtGear-1173182562726526/about/

2 Bodystorming is a technique that is comparable to brainstorming, but where the participants use their bodily expression to create or represent ideas about the issues and themes that the theatre workshop addressed (Santos, Garcia, Alves, \& Silveira, 2018).

${ }^{3}$ Playback Theatre (PT) is a community theatre method that was created by Jonathan Fox in the 1970s and is based on improvisational theatre. The idea is to build community by listening to personal stories that are told by the audience and then seeing these stories represented by a team of professional actors, an emcee (the conductor), and sometimes, a musician (Fox, 2007). In the My Stage project, instead of professional actors, the workshop participants acted out the stories told by other participants. 